\title{
Extranodal marginal zone lymphoma of the uterine cervix with concomitant copy number gains of the MALT1 and BCL2 genes: A case report
}

\author{
TOMOKO TAKIMOTO $^{1}$, SAORI MAEGAWA ${ }^{1}$, HIROSHI TATSUMI ${ }^{2}$, HISAO NAGOSHI $^{1}$, \\ YOSHIAKI CHINEN $^{1}$, YUJI SHIMURA ${ }^{1}$, TSUTOMU KOBAYASHI ${ }^{1}$, SHIGEO HORIIKE ${ }^{1}$, \\ SHIGEO NAKAMURA ${ }^{3}$, JO KITAWAKI ${ }^{2}$, JUNYA KURODA ${ }^{1}$ and MASAFUMI TANIWAKI ${ }^{1}$
}

\begin{abstract}
Departments of ${ }^{1}$ Hematology and Oncology, and ${ }^{2}$ Obstetrics and Gynecology, Kyoto Prefectural University of Medicine, Graduate School of Medical Science, Kyoto 602-8566; ${ }^{3}$ Department of Pathology and Laboratory Medicine,

Nagoya University Hospital, Nagoya 466-8550, Japan
\end{abstract}

Received February 18, 2016; Accepted January 31, 2017

DOI: $10.3892 / \mathrm{ol} .2017 .5944$

\begin{abstract}
Extranodal marginal zone lymphoma (EMZL) of mucosa-associated lymphoid tissue (MALT) of the uterus is rare, and the etiology, pathophysiology and cytogenetic features remain unknown at present. The present study reports a case of a 71-year-old female with EMZL of the uterine cervix that was $80 \mathrm{~mm}$ in diameter and invaded directly into the rectal serosa. Complete remission was successfully induced by 6 courses of immunochemotherapy with rituximab plus cyclophosphamide, doxorubicin, vincristine and prednisolone. Although the metaphase spread of the tumor cells was unavailable for whole cytogenetic analysis, fluorescence in situ hybridization (FISH) detected triple signals for MALT1 and B-cell lymphoma 2, located at chromosome $18 \mathrm{q} 21$, and the centromere of chromosome 18 , which was suggestive of trisomy 18 , and in combination with previous studies, suggested a possible association between trisomy 18 and the large tumor at initial presentation in the present patient. In addition, FISH examination detected immunoglobulin heavy chain gene rearrangement, although the translocation partner was unconfirmed. A total of 18 previously-studied patients with EMZL of the uterus, including that of the present study, were reviewed with respect to their clinical features and treatment and cytogenetic abnormality. In the evaluation of the English scientific literature, this is the first reported patient with EMZL of the uterus with partly determined cytogenetic abnormalities.
\end{abstract}

Correspondence to: Dr Junya Kuroda, Department of Hematology and Oncology, Kyoto Prefectural University of Medicine, Graduate School of Medical Science, 465 Kajii-cho, Kyoto 602-8566, Japan E-mail: junkuro@koto.kpu-m.ac.jp

Key words: uterus, extranodal marginal zone lymphoma, trisomy 18 , FISH

\section{Introduction}

Extranodal marginal zone lymphoma (EMZL) of mucosaassociated lymphoid tissue (MALT) is a subtype of indolent non-Hodgkin lymphoma that develops in the extranodal organs, such as the stomach, salivary glands, ocular adrexa and the thyroid (1). Repeated cytogenetic alterations include reciprocal chromosomal translocations such as $\mathrm{t}(11 ; 18)$ (q21;q21) in Helicobacter pylori infection-unassociated gastric EMZL (2), t(14;18)(q32;q21) in ocular adnexa EMZL, t(1;4) (p22;q32) in intestinal and pulmonary EMZL and numerical abnormalities such as trisomy of chromosome 3 or chromosome $18(3,4)$. These alterations are valuable as diagnostic markers and for understanding the molecular pathophysiology of the lymphomagenesis of EMZL (5). The aforementioned chromosomal translocations are usually mutually exclusive, and their frequencies vary widely depending on the primary tumor site. Furthermore, these chromosomal translocations and numerical abnormalities frequently co-exist in tumor cells from individual patients.

Primary lymphoid neoplasms of the uterus are rare, accounting for $2.0 \%$ of extranodal lymphomas and for $<0.5 \%$ of gynecologic cancer (6). In addition, the majority of primary uterus lymphomas are high-grade subtypes, such as diffuse large B-cell lymphoma (DLBCL) (7), whilst the occurrence of EMZL of the uterus is rare, with only 17 previously reported cases in the English literature (8-21), and their cytogenetic/genetic characteristics remain unknown. The present study reports a patient with primary uterine cervical EMZL with the concomitant copy number gains of MALT1 and B-cell lymphoma 2 (BCL2) genes, which are located at chromosome 18q21. As the tumor cells also harbored triple centromeres of chromosome 18 , the lymphoma cells in the patient of the present study were suggestive of trisomy 18. In addition, the clinical features of previously reported cases of EMZL of the uterus were reviewed. In this examination of the English literature, the present study is the first case of uterine cervical EMZL in which cytogenetic abnormalities were at least partly determined. 


\section{Case report}

Patient. A 71-year-old female was referred to University Hospital of Kyoto Prefectural University of Medicine (Kyoto, Japan), complaining of abnormal vaginal bleeding. She exhibited no B symptoms, such as pyrexia, night sweating or body weight loss at presentation. Vaginal examination identified abnormal thickening of the vaginal wall (Fig. 1A), and transvaginal ultrasound sonography detected a large mass, $80 \mathrm{~mm}$ in diameter, at the uterine cervix (Fig. 1B). T2-weighted magnetic resonance imaging detected a slightly high-intensity tumor at the uterus cervix that invaded directly to the rectal serosa (Fig. 1C and D). Positron emission tomography with 2-deoxy-2-(fluorine-18) fluoro-D-glucose (FDG) integrated with computed tomography also detected the presence of enlarged FDG-avid lymph nodes in the pelvis, whilst other lesions were intact (Fig. 2). The serum soluble interleukin-2 receptor level was elevated to $1230 \mathrm{U} / \mathrm{ml}$, normal range; 122-496 U/ml, whilst other laboratory tests were normal, including blood cell counts, lactate dehydrogenase, $\mathrm{C}$-reactive protein and albumin. The serum antibody test for Chlamydia trachomatis was negative. Histological examination of the biopsied specimen of the tumor revealed infiltration of small and round-shaped abnormal lymphoid cells with oval or convoluted nuclei that were positive for cluster of differentiation (CD)20, CD79a and BCL2 markers (Fig. 3A-D), but were negative for CD5, CD10, cyclin D1, BCL6, or pan-cytokeratin markers (data not shown). These results were consistent with the results obtained by flow cytometric analysis, which detected the presence of CD19-phycoerythrin (PE)-cyanin 5.1 (Beckman Coulter, Inc., Brea, CA, USA) and CD20-fluorescein isothiocyanate (FITC), but the absence of CD5-FITC or CD10-PE (BD Biosciences, San Jose, CA, USA). Additionally, flow cytometry also revealed the expression of surface immunoglobulin (Ig) $\lambda$ chain of tumor cells (data not shown). Collectively, the patient was diagnosed with EMZL, stage II according to the Ann Arbor staging system (22). The patient was treated with 6 courses of rituximab plus cyclophosphamide, doxorubicin, vincristine and prednisolone (R-CHOP): Rituximab $375 \mathrm{mg} / \mathrm{m}^{2}$ on day 1 , cyclophosphamide $750 \mathrm{mg} / \mathrm{m}^{2}$ on day 2 , doxorubicin $50 \mathrm{mg} / \mathrm{m}^{2}$ on day 2 , vincristine $1.4 \mathrm{mg} / \mathrm{m}^{2}$ on day 2 , prednisolone $100 \mathrm{mg} /$ body on days $2-6$, and attained complete response (CR). She has maintained CR for 9 months at the time of writing. Informed consent was obtained from the patient.

Procedure and result by the interphase fluorescence in situ hybridization (FISH) analysis. Single- and double-color FISH in single cell preparations of patient-derived lymphoma cells were performed as previously described (23). In addition, FISH was performed on paraffin-embedded tissue sections, tissue-FISH, according to previously described methods (24). The LSI Dual Color sets for the IGH Break Apart Rearrangement Probe (Abbott Molecular Inc., catalog no. 8L63-20), a mixture of 2 probes that hybridize to opposite sides of the joining gene segment through constant regions of the Immunoglobulin heavy chain $(\mathrm{IgH})$ locus, were used to detect chromosomal breakage at the $I g H$ gene. The LSI Dual Color set for the MALT1 Break Apart Rearrangement Probe was utilized to detect the gene rearrangement of MALTI. The
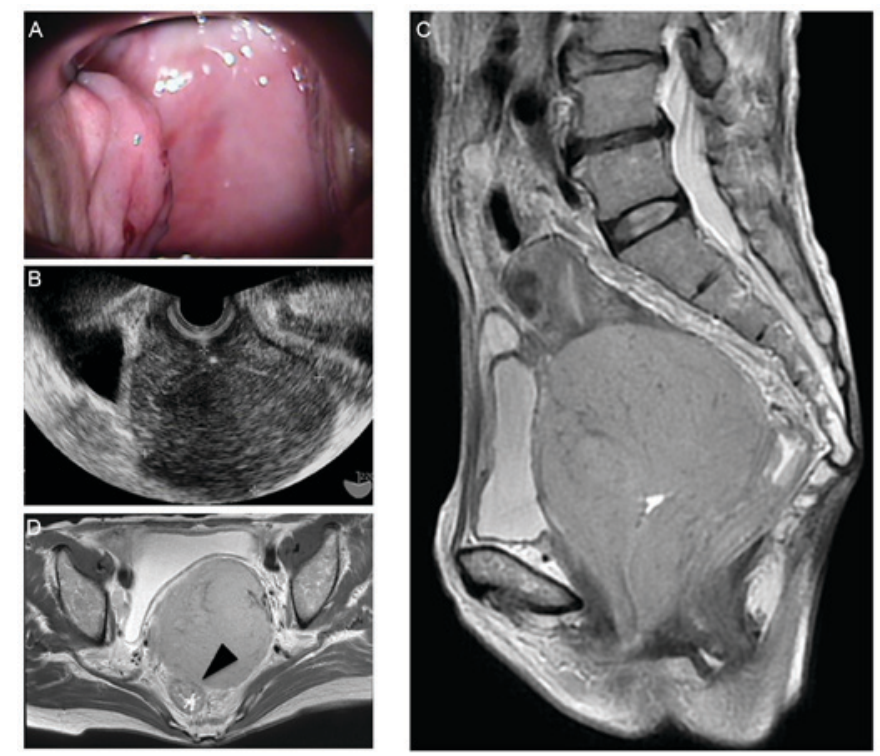

Figure 1. Gross appearance of uterine cervical tumor. (A) Vaginal examination identified the abnormally thickened vaginal wall and (B) transvaginal ultrasound sonography detected a large mass, $80 \mathrm{~mm}$ in diameter, adjacent to the cervix. (C) Transverse and (D) sagittal T2-weighed magnetic resonance imaging detected a slightly high-intensity tumor at the uterine cervix that directly invaded the rectal serosa (triangle).
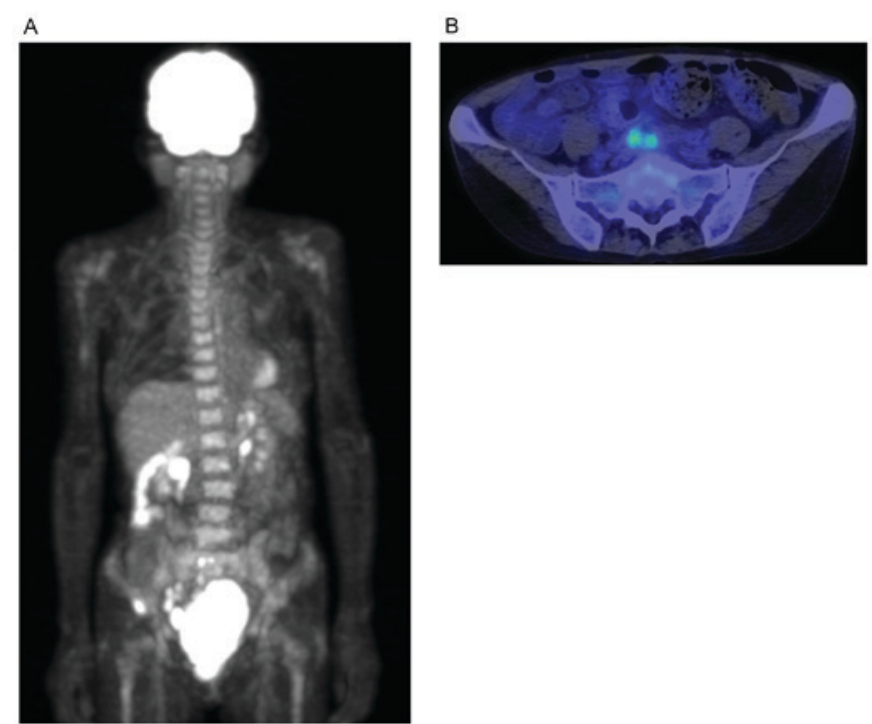

Figure 2. PET findings of ${ }^{18} \mathrm{~F}-\mathrm{FDG}$ PET/CT. ${ }^{18} \mathrm{~F}-\mathrm{FDG} \mathrm{PET} / \mathrm{CT}$ revealed the presence of (A) a FDG-avid large tumor (coronary image of the whole body) and (B) enlarged lymph nodes in the pelvis (transverse image of the pelvis). PET, positron emission tomography; ${ }^{18} \mathrm{~F}-\mathrm{FDG} \mathrm{PET} / \mathrm{CT}, 2$-deoxy-2-(fluorine-18) fluoro-D-glucose integrated with computed tomography.

LSI Dual Color sets for the fusion genes of MALT1/API2, MALT1/IgH, BCL2/IgH, or MYC/IgH (Abbott Molecular Inc., Des Plaines, Ill., USA) were also utilized in the present study. Vysis Chromosomes Enumeration Probe 18 (CEP18) (catalog no. 05J08-028; Abbott Molecular Inc.) was used to detect the centromeric region of chromosome 18.

As the metaphase spreads were unavailable due to the lack of dividing cells in the biopsied specimens, the cytogenetic studies were performed using interphase FISH. Although the FISH probes that specified chromosomal translocations 
Table I. List of cases of extranodal marginal zone lymphoma of mucosa-associated lymphoid tissue of the uterus.

\begin{tabular}{|c|c|c|c|c|c|c|c|c|c|c|c|c|c|}
\hline & \multirow[b]{2}{*}{ Age } & \multirow{2}{*}{$\begin{array}{l}\text { Clinical } \\
\text { presentation }\end{array}$} & \multirow[b]{2}{*}{ Site } & \multicolumn{3}{|c|}{ Gross appearance } & \multirow[b]{2}{*}{ Stage } & \multirow[b]{2}{*}{ Treatment } & \multicolumn{3}{|c|}{ FISH } & \multirow[b]{2}{*}{ Other } & \multirow[b]{2}{*}{ (Refs.) } \\
\hline & & & & Normal & Polyp & Tumor & & & $\mathrm{t}(11 ; 18)$ & $\mathrm{t}(14 ; 18)$ & $\mathrm{t}(1 ; 14)$ & & \\
\hline 1 & 80 & $\begin{array}{l}\text { Vaginal } \\
\text { prolapse }\end{array}$ & Corpus & + & - & - & II & Hysterectomy & Neg. & Neg. & Neg. & - & (7) \\
\hline 2 & 58 & Incidental & Corpus & + & - & - & I & Hysterectomy & Neg. & Neg. & - & - & (8) \\
\hline 3 & 46 & Bleeding & Corpus & + & - & - & I & Hysterectomy & Neg. & Neg. & - & - & (8) \\
\hline 4 & 59 & Bleeding & Corpus & + & - & - & I & Hysterectomy & Neg. & Neg. & - & - & (8) \\
\hline 5 & 72 & Bleeding & Corpus & + & - & - & I & None & Neg. & Neg. & - & - & (8) \\
\hline 6 & 61 & Incidental & Corpus & + & - & - & I & Hysterectomy & - & Neg. & - & - & (9) \\
\hline 7 & 43 & Bleeding & Corpus & + & - & - & II & $\begin{array}{l}\text { TAH-BSO+LN } \\
\text { sampling }\end{array}$ & - & - & - & - & (10) \\
\hline 8 & 47 & Dysmenorrhea & Corpus & + & - & - & I & TAH-BSO & - & - & - & - & (11) \\
\hline 9 & 52 & Bleeding & Corpus & + & - & - & IV & TAH-BSO & - & - & - & - & (12) \\
\hline 10 & 77 & Incidental & Corpus & + & - & - & I & Hysterectomy & - & - & - & - & (13) \\
\hline 11 & 81 & Incidental & Corpus & - & + & - & I & - & - & - & - & - & (14) \\
\hline 12 & 55 & Bleeding & Corpus & - & + & - & I & TAH-BSO & - & - & - & - & (15) \\
\hline 13 & 65 & Bleeding & Corpus & - & + & - & I & TAH-BSO & - & - & - & - & (16) \\
\hline 14 & 72 & Dysurea & Corpus & - & - & + & II & $\mathrm{TAH}+\mathrm{RT}$ & - & - & - & - & $(17)$ \\
\hline 15 & 46 & Bleeding & Cervix & - & + & - & IV & $\begin{array}{l}\text { ProMACE/ } \\
\text { CtyaBOM hysterectomy }\end{array}$ & - & - & - & - & (18) \\
\hline 16 & 56 & $\begin{array}{l}\text { Vaginal } \\
\text { spotting }\end{array}$ & Cervix & - & - & + & I & $\begin{array}{l}\text { Hysterectomy with } \\
\text { bilateral salpingo- } \\
\text { oophermectomy+ } \\
\text { RT+Rit }\end{array}$ & - & - & - & - & (19) \\
\hline 17 & 53 & $\begin{array}{l}\text { Cervical } \\
\text { dysplasia }\end{array}$ & Cervix & + & - & - & I & Conization & - & - & - & - & (20) \\
\hline 18 & 71 & Bleeding & $\begin{array}{l}\text { Cervix, } \\
\text { Vagina }\end{array}$ & - & - & + & II & R-CHOP & Neg. & Neg. & Neg. & $\begin{array}{c}\text { Trisomy } \\
18\end{array}$ & $\begin{array}{l}\text { Present } \\
\text { study }\end{array}$ \\
\hline
\end{tabular}

FISH, fluorescence in situ hybridization; BSO, bilateral salpingo-oopherectomy; TAH, total abdominal hysterectomy; LN, lymph node; proMACE/cytaBOM, cyclophosphamide, epirubicin, etoposide, prednisone, cytarabine, vincristine, bleomycin and methotrexate; RT, radiation therapy; Rit; rituximab; Neg., negative; R-CHOP, rituximab, cyclophosphamide, doxorubicin, vincristine, prednisolone.

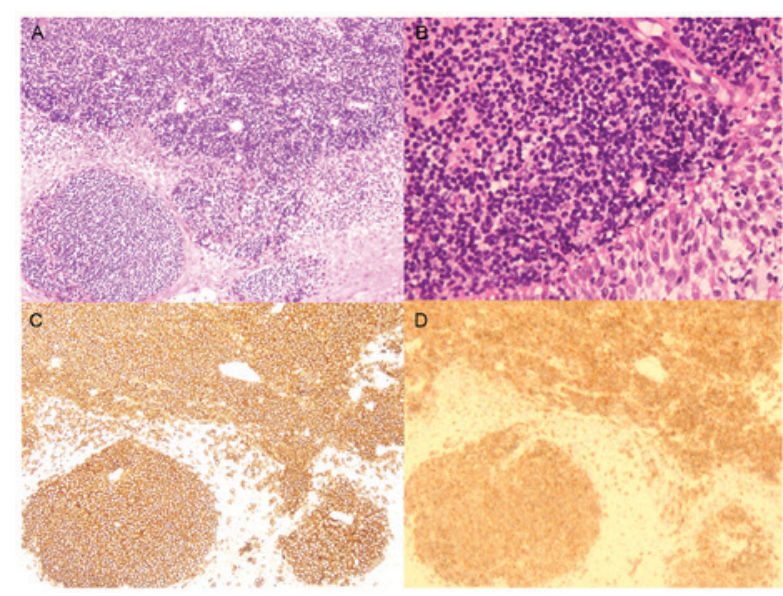

Figure 3. Histological findings. Hematoxylin \& eosin staining of a biopsied specimen from the uterine cervical tumor revealed infiltration of small and round-shaped abnormal lymphoid cells with oval or convoluted nuclei in the uterine cervix, leading to the diagnosis of extranodal marginal zone lymphoma at (A) magnification, x100 and (B) magnification, x400 (light microscope). Immunohistochemical staining using the Ventana iVIEW DAB Universal Kit (Ventana Medical Systems, Inc., Oro Valley, AZ, USA) revealed that the abnormal lymphoid cells expressed (C) cluster of differentiation 20 stained with anti-CD20 antibody (L26) (Roche Diagnostics, Branchburg, NJ, USA) at magnification, x100 and (D) B-cell lymphoma 2 stained with anti-BCL2 antibody (clone 124) (Dako; Agilent Technologies, Inc., Santa Clara, CA, USA) at magnification, x100.

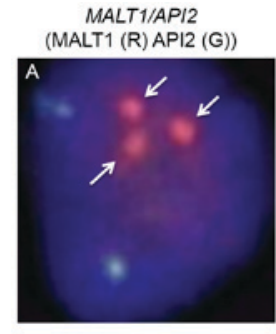

CEP 18
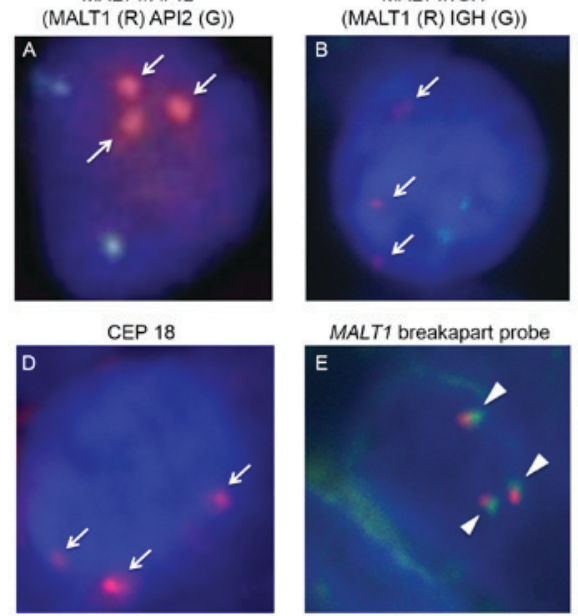

Figure 4. FISH analyses. (A-C) Whilst double-color FISH analyses for the API2/MALT1, IgH/MALT1, and IgH/BCL2 fusion genes were negative, these examinations revealed that the tumor cells harbored triple copies of (A, B) MALT1 (arrows) and (C) BLC2 (arrowheads). The tumor cells harbored (D) three centromeres of chromosome 18 (arrow), whilst (E) the MALT1 gene was not rearranged (arrowheads). (F) FISH evaluation also identified the $I g H$ split signal, indicating the presence of $I g H$ gene rearrangement (arrow). FISH, fluorescence in situ hybridization; CEP, chromosome enumeration probe; MALT1, mucosa associated lymphoid tissue lymphoma translocation gene $1 ; \mathrm{IgH}$, immunoglobulin heavy locus; BCL2, B-cell lymphoma 2. 
at $\mathrm{t}(11 ; 18)(\mathrm{q} 21 ; \mathrm{q} 21)$ for the MALT1/API2 fusion gene, $\mathrm{t}(14 ; 18)$ (q32;q21) for the MALT1/IgH fusion gene and $\mathrm{t}(14 ; 18)(\mathrm{q} 32 ; \mathrm{q} 21)$ for the $B C L 2 / I g H$ fusion genes did not demonstrate the presence of the respective fusion genes, these examinations identified that the tumor cells harbored triple copies of the MALT1 and BCL2 genes (Fig. 4A-C). In addition, the tumor cells also harbored three signals for chromosome enumeration probe 18 , indicating the existence of centromeres of chromosome 18 (Fig. 4D), and three copies of the non-rearranged MALT1 gene (Fig. 4E). Collectively, these results suggested the existence of trisomy 18 in the tumor cells. Whilst the FISH examination also identified the $I g H$ split signal, which indicated the presence of $\mathrm{IgH}$ translocation, the translocation partner, including $c-M Y C$ (MYC), was not identified (Fig. 4F and data not shown).

\section{Discussion}

Fox and More (25) defined the criteria for the diagnosis of primary extranodal lymphoma of the uterus as follows: Clinically confined to the uterus, no evidence of leukemia and along interval between the appearance of primary uterine lymphoma and the secondary tumor. The patient of the present study fulfilled these criteria. Amongst the previously reported cases of uterine EMZLs, including the patient of the present study (Table I), the development of EMZLs in the uterine cervix were even more rare, with only 4 reported patients (19-21). With respect to the gross appearance of the tumors of 18 cases, 15 were small in size, located in grossly normal epithelium or in small polyps, and were incidentally identified by the screening biopsy (Cases 1-13, 15 and 17 in Table I). Large tumors, as in the patient of the present study, were extremely rare. Cytogenetic analyses using FISH were administered to 6 previously reported cases, yet they failed to detect any particular chromosomal abnormalities (Cases $1-6$ in Table I) $(8,9)$. In the patient of the present study, trisomy 18 and $\mathrm{IgH}$ translocation were suspected, although not determined definitively due to the lack of sufficient material for metaphase spreads. Thus, the present study is the first study to identify partial chromosomal abnormalities in EMZL of the uterus.

Trisomy 18 has been associated with the levels of clinical aggression in gastric EMZL (26). In addition, Sugimoto et al (27) reported a case of DLBCL of the uterus harboring trisomy 18 that was suspected to have been transformed from EMZL. These suggest a potential association between trisomy 18 and the large tumor at initial presentation in the present study. Conversely, whilst rearrangement of the $\mathrm{IgH}$ gene in the lymphoma cells was identified in the present patient, the translocation partner was not. Furthermore, investigation of the $\mathrm{t}(8 ; 14)(\mathrm{q} 24 ; \mathrm{q} 32)$ for the $I g H / M Y C$ fusion gene was negative (data not shown). In addition, as the immunohistochemical analysis revealed that BCL6 was negative in the tumor specimen, the $\mathrm{t}(3 ; 14)(\mathrm{q} 27 ; \mathrm{q} 32)$ alteration was unlikely to exist. Thus, the pathogenic involvement of the $\mathrm{IgH}$ translocation remains unknown in the present study.

Whilst localized therapies, including surgical resection and radiotherapy, have been generally adapted to EMZL in the limited disease stage, systemic immunochemotherapy $\mathrm{R}-\mathrm{CHOP}$ as the initial treatment was administered to the patient in the present study for several reasons. Firstly, the large tumor invaded directly to the rectal serosa at presentation, and radiotherapy was considered high risk for rectal penetration or rupture. It was also anticipated that the wide field irradiation for the large tumor may lead to unwanted adverse events in the pelvic viscera. Secondly, surgical resection was also excluded, as complete resection of the large tumor and the additionally involved lymph nodes required pelvic evisceration. To avoid those invasive therapy-associated complications, systemic immunochemotherapy was selected. However, EMZL is generally a clinically indolent disease with a 5-year overall survival ranging from 86 to $100 \%(28,29)$. The optimal approach for the management of uterine EMZL has not yet been established, and the treatment choice should be carried in consideration of the tumor site, disease stage and clinical manifestations on an individual basis. In conclusion, the present study reports the first case of uterine cervical EMZL with trisomy 18 and $I g H$ translocation with an unknown partner, as detected by FISH analyses.

\section{Acknowledgements}

The authors are grateful to Ms. M Minatani and Ms. C Ikawa for their excellent technical support. The present study was supported in part by Grants-in-Aid for Scientific Research from the Ministry of Education, Culture, Sports, Science and Technology of Japan (grant nos. J142004051, J152001060 and J162004043).

\section{References}

1. Isaacson PG: Update on MALT lymphomas. Best Pract Res Clin Haematol 18: 57-68, 2005.

2. Liu H, Ye H, Ruskone-Fourmestraux A, De Jong D, Pileri S, Thiede C, Lavergne A, Boot H, Caletti G, Wündisch T, et al: $\mathrm{T}(11 ; 18)$ is a marker for all stage gastric MALT lymphomas that will not respond to $\mathrm{H}$. pylori eradication. Gastroenterology 122: 1286-1294, 2002.

3. Murga Penas EM, Hinz K, Röser K, Copie-Bergman C, Wlodarska I, Marynen P, Hagemeijer A, Gaulard P, Löning T, Hossfeld DK and Dierlamm J: Translocations t(11;18)(q21;q21) and $\mathrm{t}(14 ; 18)(\mathrm{q} 32 ; \mathrm{q} 21)$ are the main chromosomal abnormalities involving MLT/MALT1 in MALT lymphomas. Leukemia 17: 2225-2229, 2003

4. Streubel B, Simonitsch-Klupp I, Müllauer L, Lamprecht A, Huber D, Siebert R, Stolte M, Trautinger F, Lukas J, Püspök A, et al: Variable frequencies of MALT lymphoma-associated genetic aberrations in MALT lymphomas of different sites. Leukemia 18: 1722-1726, 2004.

5. Streubel B, Lamprecht A, Dierlamm J, Cerroni L, Stolte M, Ott G, Raderer M and Chott A: T(14;18)(q32;q21) involving IGH and MALT1 is a frequent chromosomal aberration in MALT lymphoma. Blood 101: 2335-2339, 2003.

6. Kosari F, Daneshbod Y, Parwaresch R, Krams M and Wacker HH: Lymphomas of the female genital tract: A study of 186 cases and review of the literature. Am J Surg Pathol 29: 1512-1520, 2005.

7. Harris NL and Scully RE: Malignant lymphoma and granulocytic sarcoma of the uterus and vagina. A clinicopathologic analysis of 27 cases. Cancer 53: 2530-2545, 1984.

8. Wright TM, Rule S, Liu H, Du MQ and Smith ME: Extranodal marginal zone lymphoma of the uterine corpus. Leuk Lymphoma 53: 1831-1834, 2012.

9. Tahmasebi FC, Roy S, Kolitz JE, Sen F, Laser J and Zhang X: Primary extranodal marginal zone lymphoma of the endometrium: Report of four cases and review of literature. Int J Clin Exp Pathol 8: 3036-3044, 2015.

10. Heeren JH, Croonen AM and Pijnenborg JM: Primary extranodal marginal zone B-cell lymphoma of the female genital tract: A case report and literature review. Int J Gynecol Pathol 27: 243-246, 2008 
11. Frey NV, Svoboda J, Andreadis C, Tsai DE, Schuster SJ, Elstrom R, Rubin SC and Nasta SD: Primary lymphomas of the cervix and uterus: The university of Pennsylvania's experience and a review of the literature. Leuk Lymphoma 47: 1894-1901, 2006.

12. Nezhat $\mathrm{CH}$, Dun EC, Wieser F and Mauricio Z: A rare case of primary extranodal marginal zone B-cell lymphoma of the ovary, fallopian tube, and appendix in the setting of endometriosis. Am J Obstet Gynecol 208: e12-e14, 2013.

13. Hamadani M, Kharfan-Dabaja M, Kamble R, Kern W and Ozer H: Marginal zone B-cell lymphoma of the uterus: A case report and review of the literature. J Okla State Med Assoc 99: 154-156, 2006.

14. Merritt AJ, Shenjere P, Menasce LP, Reid F, Diss T, McVey RJ and Byers RJ: Primary extranodal marginal zone $B$ cell lymphoma of the uterus: A case study and review of the literature. J Clin Pathol 67: 375-377, 2014.

15. Annibali O, Romeo AA, Agostinelli C, Marchesi F, Natale A, De Muro M, Tirindelli MC, Pileri SA and Avvisati G: A case of primary MALT lymphoma of the endometrium presenting as an asymptomatic polyp. Ann Hematol 88: 491-493, 2009.

16. Di Tucci C, Pecorella I, Palaia I and Benedetti Panici P: Endometrial marginal zone B-cell MALT-type lymphoma: Case report and literature review. Crit Rev Oncol Hematol 88: 246-252, 2013

17. Iyengar P and Deodhare S: Primary extranodal marginal zone B-cell lymphoma of MALT type of the endometrium. Gynecol Oncol 93: 238-241, 2004.

18. Ballesteros E, Osborne BM and Matsushima AY: CD5+ low-grade marginal zone B-cell lymphomas with localized presentation. Am J Surg Pathol 22: 201-207, 1998.

19. Rossi G, Bonacorsi G, Longo L, Artusi T and Rivasi F: Primary high-grade mucosa-associated lymphoid tissue-type lymphoma of the cervix presenting as a common endocervical polyp. Arch Pathol Lab Med 125: 537-540, 2001.

20. Coon D, Beriwal S, Swerdlow SH and Bhargava R: Mucosa-associated lymphoid tissue lymphoma of the cervix. J Clin Oncol 26: 503-504, 2008

21. Vang R, Medeiros LJ, Ha CS and Deavers M: Non-Hodgkin's lymphomas involving the uterus: A clinicopathologic analysis of 26 cases. Mod Pathol 13: 19-28, 2000.
22. Lister TA, Crowther D, Sutcliffe SB, Glatstein E, Canellos GP, Young RC, Rosenberg SA, Coltman CA and Tubiana M: Report of a committee convened to discuss the evaluation and staging of patients with Hodgkin's disease: Cotswolds meeting. J Clin Oncol 7: 1630-1636, 1989.

23. Kuroda J, Matsumoto Y, Tanaka R, Kurita K, Kobayashi T, Shimizu D, Kimura S, Ashihara E, Horiike S, Shimazaki C and Taniwaki M: JAK2V617F-positive essential thrombocythemia and multiple myeloma with IGH/CCND1 gene translocation coexist, but originate from separate clones. Acta Haematol 120: 177-181, 2008.

24. Matsumoto Y, Nomura K, Matsumoto S, Ueda K, Nakao M, Nishida K, Sakabe H, Yokota S, Horiike S, Nakamine H, et al: Detection of $t(14 ; 18)$ in follicular lymphoma by dual-color fluorescence in situ hybridization on paraffin-embedded tissue sections. Cancer Genet Cytogenet 150: 22-26, 2004.

25. Fox H and More JR: Primary malignant lymphoma of the uterus. J Clin Pathol 18: 723-728, 1965.

26. Nakamura S, Ye H, Bacon CM, Goatly A, Liu H, Banham AH, Ventura R, Matsumoto T, Iida M, Ohji Y, et al: Clinical impact of genetic aberrations in gastric MALT lymphoma: A comprehensive analysis using interphase fluorescence in situ hybridization. Gut 56: 1358-1363, 2007.

27. Sugimoto KJ, Imai H, Shimada A, Wakabayashi M, Sekiguchi Y, Nakamura N, Sawada T, Izumi H, Ota Y, Komatsu N and Noguchi M: Diffuse large B-cell lymphoma of the uterus suspected of having transformed from a marginal zone B-cell lymphoma harboring trisomy 18: A case report and review of the literature. Int J Clin Exp Pathol 6: 2979-2988, 2013.

28. Thieblemont C, Berger F, Dumontet C, Moullet I, Bouafia F, Felman P, Salles G and Coiffier B: Mucosa-associated lymphoid tissue lymphoma is a disseminated disease in one third of 158 patients analyzed. Blood 95: 802-806, 2000.

29. Zinzani PL, Magagnoli M, Galieni P, Martelli M, Poletti V, Zaja F, Molica S, Zaccaria A, Cantonetti AM, Gentilini P, et al: Nongastrointestinal low-grade mucosa-associated lymphoid tissue lymphoma: Analysis of 75 patients. J Clin Oncol 17: 1254, 1999. 